\title{
Bulbourethral Gland Secretion
}

National Cancer Institute

\section{Source}

National Cancer Institute. Bulbourethral Gland Secretion. NCI Thesaurus. Code C52554.

The clear viscous liquid produced by the bulbourethral (Cowper) gland that lubricates the urethra in preparation for the passage of sperm. 